\title{
Heat conduction on pan using portable parabolic stove with addition of flat mirror
}

\author{
Benedictus Mardwianta $^{1 *}$, Abdul Haris Subarjo ${ }^{2}$, Wayan Wiardefan ${ }^{3}$ \\ ${ }^{1,2,3}$ Departemen Teknik Mesin Sekolah Tinggi Teknologi Adisutjipto \\ Email Korespondensi : *aries2144@yahoo.com
}

\begin{abstract}
This research aims to develop the parabolic stove with addition of some flat mirrors around the parabolic mirror. It will increase the heat transfer of conduction in the pan. The parabolic itself has around and concave shape, making it suitable for concentrating solar energy. The experimental method was carried out in this research and the test was carried out in an open space with solar radiation intensities with ranging from $169.6 \mathrm{~W} / \mathrm{m}^{2}$ to $974.4 \mathrm{~W} / \mathrm{m}^{2}$. The results of heat conduction on a pan without the addition of a flat mirror generate a 105.15 Watt, addition of one flat mirror will generate a 174.82 Watt, addition of two flat mirrors will generate a 259.24 Watt, addition of three flat mirrors will generate a 342.79 Watt and addition of four flat mirrors will generate a 412.26 Watt. The heat conduction depends on the intensity of the sun caught by the reflector. If the sun intensity decreases, the surface temperature between of the outer pan wall (T1) and the inner wall temperature (T2) will decrease too.
\end{abstract}

Keywords: Heat conduction, sun intensity, parabolic stove

\section{Pendahuluan}

Matahari pada dasarnya adalah reaktor yang mencampur unsur-unsur gas dengan terus menerus. Beberapa hasil pencampuran unsur gas di radiasikan oleh matahari. Salah satu proses yang paling penting adalah dimana hidrogen (4 - proton) dicampur dengan helium (satu inti helium) massa dari satu inti helium lebih kecil dibandingkan dengan 4 proton, helium menghilang saat terjadi reaksi ketika pencampuran dan diubah menjadi energi. Radiasi surya (solar radiation) merupakan suatu bentuk radiasi termal yang mempunyai distribusi panjang gelombang yang khusus. Intensitasnya sangat bergantung dari kondisi atmosfer, saat dalam tahun, dan sudut timpa (angle of incidence) sinar Matahari dipermukaan bumi. Pada batas luar atmosfer, iradiasi surya total ialah $1395 \mathrm{~W} / \mathrm{m}^{2}$ bilamana bumi berada pada jarak rata-ratanya dari Matahari. Cahaya berjalan menempu garis lurus pada berbagai keadaan [1]. Sebagai contoh, sebuah sumber cahaya titik seperti matahari menghasilkan bayangan, dan sinar sinar lampu senter tampak merupakan garis lurus. Cahaya berjalan dalam lintasan yang berbentuk garis lurus disebut berkas cahaya. Cahaya pun dapat dianggap sebagai gelombang elektromagnetik. Walaupun model berkas cahaya tidak menangani aspek cahaya ini, model berkas telah berhasil dalam mendeskripsikan banyak aspek cahaya seperti pantulan, pembiasan, dan pembentukan bayangan oleh cermin dan lensa. Ketika cahaya menimpa permukaan benda, sebagian cahaya dipantulkan. Sisanya di serap oleh benda (dan diubah menjadi energi panas) atau jika benda tersebut transparan seperti kaca atau air, sebagian diteruskan. Untuk benda-benda yang sangat mengkilat seperti cermin berlapis perak, lebih dari 95 persen cahaya bisa dipantulkan. Untuk permukaan-permukaan yang rata ternyata berkas sinar datang dan pantul berada pada bidang yang sama dengan garis normal permukaan dan bahwa sudut datang sama dengan sudut pantul. Kompor surya parabola adalah kompor tenaga matahari yang memanfaatkan pantulan dari radiasi matahari yang langsung di konsentrasikan ke panci [2]. Kompor surya parabola sangat efisien tetapi memerlukan perhatian pada saat pengunaan untuk menjaga sinar matahari tetap fokus ke panci agar diperoleh kinerja yang baik. 
Perpindahan panas (Heat Transfer) adalah energi (kalor) yang di pindahkan akibat adanya perbedaan gradien suhu, jika pada suatu benda terdapat gradien suhu maka akan terjadi perpindahan energi dari bagian bersuhu tinggi ke bagian yang bersuhu rendah [3]. Ada tiga macam mekanisme perpindahan panas yang berbeda yaitu perpindahan panas secara konduksi, konveksi dan radiasi. Perpindahan panas konduksi menggunakan rumus

$$
\mathrm{q}=-\mathrm{kA}(\mathrm{T} 2-\mathrm{T} 1) / \Delta \mathrm{x}
$$

keterangan:

$$
\begin{array}{ll}
\mathrm{q} & =\text { aliran kalor }(\mathrm{W}), \mathrm{k}=\text { konduktivitas termal }(\mathrm{W} / \mathrm{m} . \mathrm{K}), \mathrm{A}=\text { luas permukaan }\left(\mathrm{m}^{2}\right) \\
\mathrm{T} 1 & =\text { temperatur titik fokus pada bagian bawah panci }(\mathrm{K}) \\
\mathrm{T} 2 & =\text { temperatur permukaan pada bagian dalam panci }(\mathrm{K}), \Delta \mathrm{x}=\text { tebal dinding }(\mathrm{m})
\end{array}
$$

Tanda (-) digunakan untuk memenuhi hukum kedua Termodinamika yaitu kalor mengalir ke tempat yang lebih rendah dalam skala temperatur.

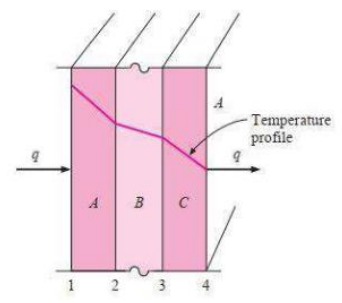

Gambar 1. Perpindahan Kalor Melalui Dinding

(Sumber: Holman, 1997)

Penelitian tentang "Rancang Bangun Kolektor Panas Matahari Jenis Palung Parabola Dengan Sistem Pelacakan Matahari Menggunakan Sensor Ldr", menjelaskan banyak jenis kolektor surya telah digunakan untuk menyerap energi panas matahari sebanyak mungkin salah satunya adalah kolektor panas matahari jenis palung parabola [4]. Dalam penelitiannya kolektor panas matahari yang dilengkapi dengan sistem pelacakan matahari dibangun dan dipelajari. Sistem ini terdiri dari kolektor panas menggunakan plat stainless steel dengan lebar $0,9 \mathrm{~m}$, panjang $1,83 \mathrm{~m}$, jarak fokus $0,225 \mathrm{~m}$ dengan sudut rim $90^{\circ}$, pipa stainless steel dengan diameter $0,019 \mathrm{~m}$ dibuat untuk penerima, dan sistem pelacakan menggunakan aktuator parabola 12 VDC dan sensor LDR. Tes menunjukkan bahwa ketidaktepatan antara sudut kolektor dan matahari mendekati $12^{\circ}$ dengan rata-rata $7^{\circ}$. Pengujian model kolektor panas tanpa sistem pelacakan selama 2 jam dan 5 menit menghasilkan total $111,7 \mathrm{~kJ}$ dan total $2737,6 \mathrm{~kJ}$ sehingga total efisiensi panas adalah $4,1 \%$. Pengujian untuk kolektor panas menggunakan sistem pelacakan menghasilkan total $244,3 \mathrm{~kJ}$ dan total $3503 \mathrm{~kJ}$ sehingga total efisiensi panas adalah 6,97\%.

Penelitian tentang "Studi Eksperimen Kinerja Oven Surya Berpermukaan Bentuk Oval". Oven surya yang menjadi objek penelitian ini, memiliki desain berupa kombinasi parabola dengan setengah selinder, sehingga permukaan sinar masuk ke dalam oven surya berbentuk oval [5]. Oven surya ini memiliki luas permukaan sinar matahari masuk sebesar $1.3 \mathrm{~m} 2$, reflektor dilapisi dengan potongan cermin, dan fokus sinar terletak pada kedalaman $36 \mathrm{~cm}$ dari permukaan atas. Sedangkan di bagian atas parabola diberi penutup yang terbuat dari bahan plastik transparant. Penutup ini berfungsi melindungi absorber dari udara lingkungan. Data hasil eksperimen, memberikan informasi tentang kinerja oven surya, bahwa semakin bertambahnya volume air, maka membutuhkan energi panas yang lebih banyak. Sedangkan nilai cooking power tertinggi 646 watt diperoleh dari hasil pengujian valume air sebanyak 2 liter, dan nilai efisiensi oven surya tertinggi 0,72 diperoleh dari hasil pengujian volume air sebanyak 2 liter. Oven surya ini dapat memanggang roti dengan berat adonan sebesar $1 \mathrm{~kg}$, selama 55 menit.

Dwicaksono dan Rangkuti, (2017). Meneliti tentang "Perancangan, Pembuatan, Dan Pengujian Kompor Energi Matahari Portabel Tipe Parabola Kipas". Penelitian ini membuat desain kompor portabel dengan tipe parabola kipas berbahan plat Stainlees Steel Mirror 304. Proses pengujian dilakukan dengan menggunakan standarisasi American Society of Agricultural Engineers Standard (ASAE) S580 [6]. Hasil utama yang dicapai ialah terwujudnya sebuah purwa rupa kompor energi matahari yang portabel, desain 
mudah dirakit dan digunakan oleh seluruh kalangan usia. Selain itu pengujian ini berhasil mencapai suhu yang cukup memuaskan dalam waktu yang tidak begitu lama. Untuk Daya Masak Terstandarisasi dengan temperatur tertinggi $84^{\circ} \mathrm{C}$, Temperatur Stagnasi Terstandarisasi $84^{\circ} \mathrm{C}$, Waktu Pemanasan Sensibel Terstan- darisasi 4148,86 detik atau 69 menit, waktu Masak Tanpa Diawasi Terstandarisasi 10277,65 detik atau 171,30 menit.

Penelitian tentang Potensi "Penggunaan Kompor Energi Surya Untuk Kebutuhan Rumah Tangga". menjelaskan kebutuhan energi untuk memasak hampir diperlukan oleh setiap rumah tangga dan setiap hari, disisi lain energi matahari untuk daerah di Indonesia tersedia melimpah setiap hari khususnya saat musim kemarau, jadi penggunaan kompor energi surya untuk rumah tangga sangat tepat [7]. Untuk mengetahui lebih jauh potensi pemanfaatan energi surya untuk kebutuhan memasak dalam rumah tangga Marwani telah melakukan penelitian/ pengujian terhadap sebuah kompor energi surya tipe kolektor parabola berdiameter $166 \mathrm{~cm}$ dan aluminium foil sebagai bahan reflektornya. Dari hasil pengujian dengan berbagai kondisi radiasi termal matahari disimpulkan bahwa kompor energi surya dapat berfungsi dengan baik jika radiasi termal matahari berkisar antara $500 \mathrm{~W} / \mathrm{m}^{2}$ sampai dengan $900 \mathrm{~W} / \mathrm{m}^{2}$ selama lebih kurang 3 jam. Efisiensi maksimum kompor surya didapat sebesar $12 \%$.

Penelitian berjudul "An investigation of a solar cooker with parabolic trough concentrator". Ini menjelaskan penelitiannya yang bertujuan untuk mengembangkan model matematika sederhana untuk evaluasi kinerja kompor parabola surya yang terpapar secara termal [8]. Itu dilakukan di bawah kondisi iklim lingkungan terbuka untuk keperluan rumah tangga. Selain itu, suhu air maksimum yang dicapai adalah $37,2^{\circ} \mathrm{C}$ di outlet palung parabola. Namun, suhu air maksimum yang dicapai oleh kompor parabola adalah $53,6^{\circ} \mathrm{C}$ dalam kondisi stagnan.

\section{Metodologi Penelitian}

Metode penelitian menggunakan metode studi eksperimen dengan membuat rancangan alat kompor tenaga surya tipe parabola dengan ukuran parabola yang sudah ada di pasaran, melakukan pengujian serta pengumpulan data terhadap kompor tenaga surya, dengan metode pengambilan data yaitu percobaan pengujian alat dengan parameter waktu yang sudah ditentukan, dan kondisi cuaca lingkungan sekitar. Obyek dari pembahasan ini adalah heat transfer.

\subsection{Diagram alir penelitian}

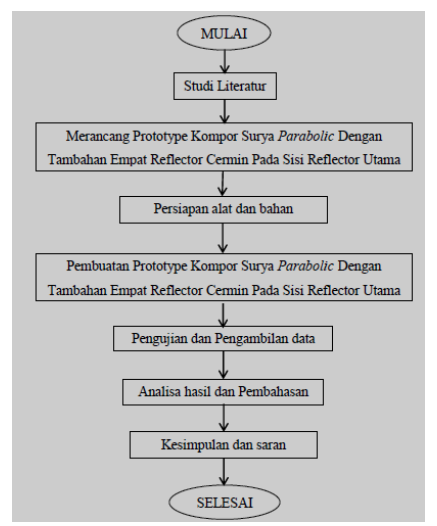

Gambar 2. Diagram Alir Penelitian

Merancang Prototype Kompor surya Parabolic memudahkan dalam pembuatan rancangan kompor tenaga surya ini penulis menggunakan software Autodesk Inventor. Tahap selanjutnya penyiapan alat dan bahan yang akan digunakan dalam penelitian sesuai dengan kebutuhan eksperimen dan juga melakukan survei dan observasi ke lapangan untuk mengetahui anggaran biaya yang diperlukan dalam pemenuhan alat dan bahan penelitian lalu mempersiapkan segala alat dan bahan yang dibutuhkan sesuai dengan spesifikasi yang sudah ditentukan. Setelah bahan dan peralatan yang dibutuhkan sudah tersedia maka langkah selanjutnya yaitu pembuatan Kompor Surya parabolic dengan menggunakan desain yang sudah dirancang menggunakan software Autodesk Inventor. Setelah Kompor Surya parabolic selesai produksi langkah selanjutnya yaitu pengujian atau percobaan dari alat yang sudah dirancang dan ditambah dengan variasi 
yang ditentukan. Setelah itu pengambilan data performa dari kompor tenaga surya dengan langkah kerja yang sudah ditentukan.

\subsection{Waktu Penelitian}

Penelitian dilakukan di kampus STTA pada tanggal 14 Februari 2020, 15 Februari 2020, 16 Februari 2020, 17 Februari 2020 dan 18 Februari 2020. Ini juga didapatkan data temperatur dan data intensitas matahari $\left(\mathrm{W} / \mathrm{m}^{2}\right)$.

\section{Hasil dan Pembahasan}

Untuk memudahkan perancangan kompor tenaga surya ini penulis menggunakan software Autodesk Inventor. Untuk memudahkan mementukan titik fokus penulis mengguakan software Parabola Calculator 2.0. Titik fokus diperoleh dengan cara memasukan diameter dan kedalaman parabola. Parabola Calculator 2.0 merupakan program dari windows yang dirancang khusus untuk menghintung dimensi ideal untuk parabola. Program ini sangat dibutuhkan untuk merancang kolektor panas matahari. Program ini memungkinkan untuk menghitung diameter, kedalamanan, panjang fokus, diameter linear, dan segmen angka. Terlebih lagi software ini dapat merepresentasikan grafis parabola, dan secara otomatis menampilkan koordinat $\mathrm{x}$ dan $\mathrm{y}$.

\subsection{Pengembangan desain}

Perancangan kompor tenaga surya ini penulis menggunakan software Autodesk Inventor.
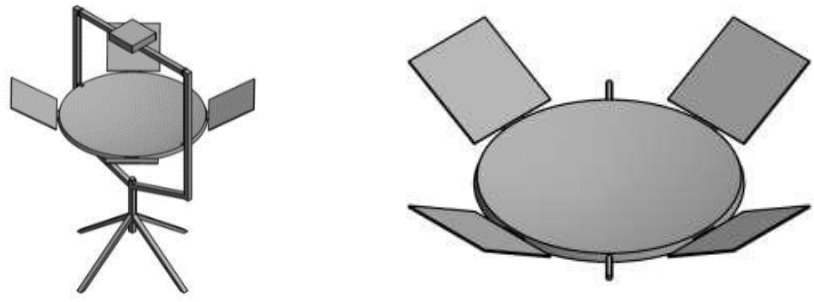

Gambar 3. Pemodelan Piringan Parabola Dengan Tambahan Empat Cermin Datar

Ukuran desain kompor adalah Diameter reflector parabola sebesar $74 \mathrm{~cm}$, ukuran satu cermin pada sisi parabola adalah $30 \times 30 \mathrm{~cm}$, panjang kaki sebesar $34.5 \mathrm{~cm}$ dan tinggi dudukan alat masak sebesar $160 \mathrm{~cm}$.

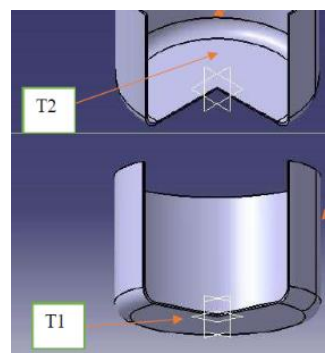

Gambar 4. Panci dengan Letak Posisi Kabel Termokopel T1 dan T2

Temperatur T1 adalah temperatur titik fokus pada permukaan bagian bawah dinding panci $(\mathrm{K})$ dan temperatur $\mathrm{T} 2$ adalah temperatur permukaan pada bagian dalam dinding panci $(\mathrm{K})$.

\subsection{Pembuatan Kompor}

Setelah dilakukan perancangan kompor menggunakan software maka perlu dilakukan pembuatan kompor tersebut. Untuk dapat melakukan proses produksi dan pengujian maka dibutuhkan alat dan bahan sebagai berikut:

Alat yang digunakan antara lain solar power meter adalah perangkat alat ukur yang menguji intensitas tenaga surya, termokopel adalah jenis sensor suhu yang digunakan untuk mendeteksi atau mengukur suhu 
melalui dua jenis logam konduktor berbeda yang digabung pada ujungnya sehingga menimbulkan efek termoelektrik, panci aluminium berbentuk silinder. Bahan yang digunakan antara lain cermin adalah bahan yang dibutuhkan untuk komponen pada kompor yang nantinya cermin ini akan di pasang atau di rekatkan pada permukaan dalam parabola dengan menggunakan Double tape, besi hollow ini digunakan untuk membuat rangka tambahan cermin yang dipasang pada sisi parabola, piringan parabola adalah alat yang digunakan untuk sebagai alas untuk cermin, pipa besi digunakan untuk rangka pada kompor tenaga surya, baut dan mur untuk menggabungkan beberapa komponen sehingga tergabung menjadi satu bagian yang memiliki sifat tidak permanen. Baut dan mur yang digunakan adalah ukuran $10 \mathrm{~mm}$ dan $12 \mathrm{~mm}$ seperti pada gambar 5 .
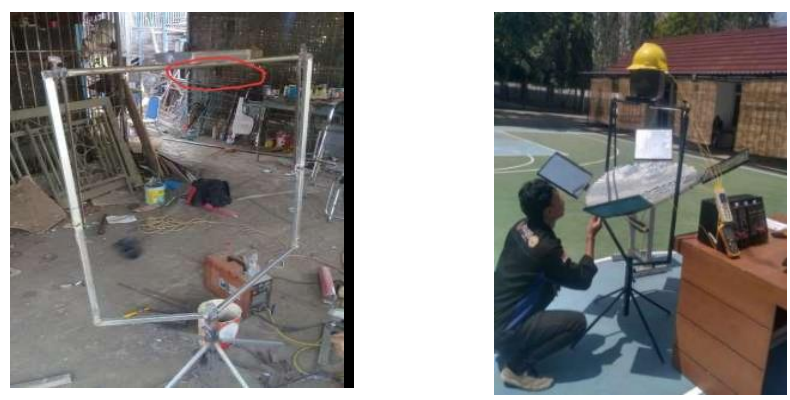

Gambar 5. Pembuatan kompor surya parabolik

\subsection{Pengujian Kompor}

Pengujian kompor surya tanpa penambahan cermin datar dan dengan penambahan empat cermin datar sangat berpengaruh pada kekuatan intensitas radiasi matahari. Hal ini disebabkan oleh sifat cermin yang dapat memantulkan sinar matahari.

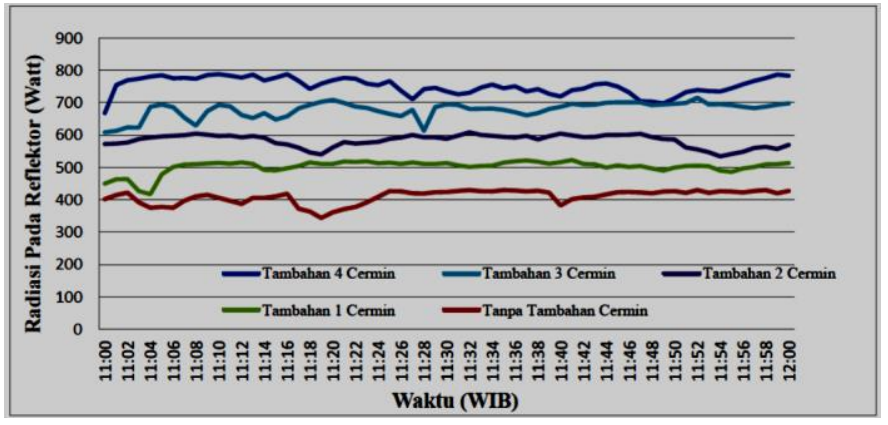

Gambar 6. Grafik Perbandingan Radiasi Pada Reflector Dengan Temperatur T1

Dari grafik di gambar 6. diatas dapat dilihat bahwa radiasi yang tertangkap oleh reflector mengalami kenaikan karena variasi yang ditambahkan. Semakin besar luasan dari reflecktor maka daya atau tangkapan radiasi matahari semakin banyak. Tetapi perlu diperhatikan saat penelitian, radiasi yang ditangkap oleh reflector harus semuanya mengenai dinding bagian bawah panci supaya tidak terjadi kesalahan perhitungan dan mendapatkan garis grafik yang menyerupai intensitas radiasi matahari yang diukur menggunakan solary meter.

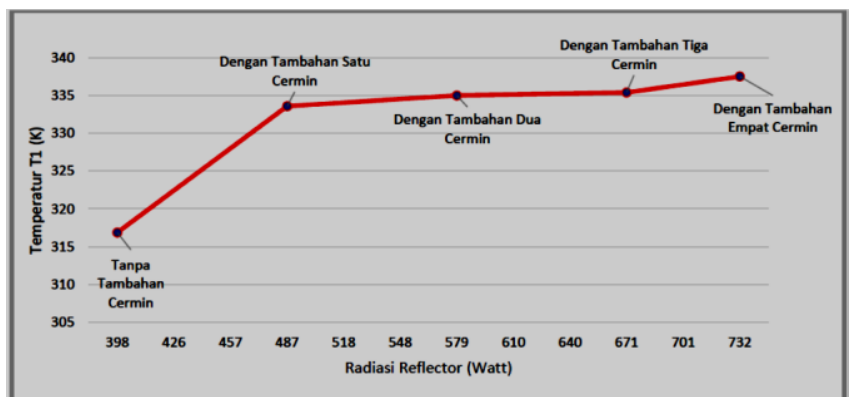

Gambar 7. Grafik Radiasi Pada Temperatur Permukaan Dinding Panci Bagian Luar (T1) 
Dari grafik di gambar 7. dapat dilihat efek dari penambahan variasi terhadap rata-rata temperature dari permukaan dinding panci bagian luar (T1). Temperatur T1 pada awalnya dari tanpa tambahan cermin mengalami kenaikan yang siknifikan setelah ditambahkan variasi satu cermin datar. Tetapi setelah itu penambahan variasi lainnya mengalami kenaikan temperatur yang tidak terlalu signifikan, ini dikarenakan kualitas bahan dari parabola dan bahan dari variasi cermin datar terlalu berat. Semakin banyak ditambah variasi maka bentuk parabola akan sedikit berubah sehingga susah untuk mangatur titik fokus dari parabola tersebut.

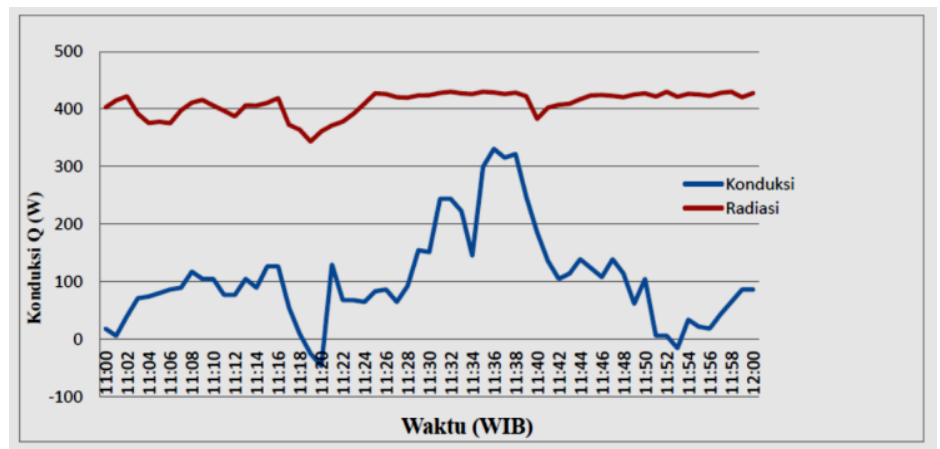

Gambar 8. Grafik Konduksi Pada Panci Tanpa Tambahan Cermin Datar

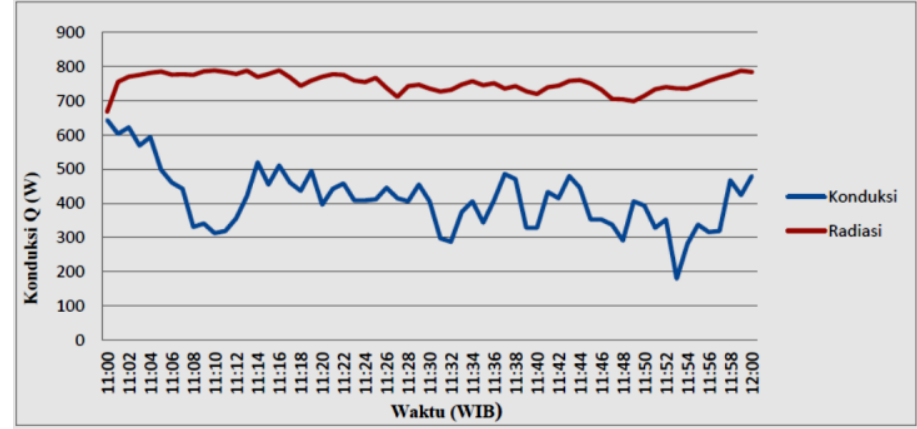

Gambar 9. Grafik Konduksi Pada Panci Dengan Tambahan Empat Cermin

Grafik gambar 8 dan gambar 9. diatas dapat dilihat perbandingan radiasi yang dipantulkan reflector terhadap proses perpindahan kalor konduksi pada panci. Perpindahan kalor konduksi tergantung dari intensitas matahari yang tertangkap oleh reflector. Jika tiba-tiba intensitas matahari menurun maka temperature permukaan dinding panci bagian luar (T1) akan menurun ini akan mengakibatkan perbedaan temperatur T1 dan temperature dinding bagian dalam (T2) akan menjadi sedikit sehingga aliran kalor konduksi pada kompor akan menurun, ini terdapat pada grafik perpindahan kalor konduksi pada kompor tanpa tambahan cermin terdapat nilai negatif pada grafik yang disebabkan temperatur T1 lebih rendah daripada temperatur T2. Dari grafik diatas juga dapat dilihat rata-rata aliran kalor konduksi mengalami peningkatan, ini dikarenakan variasi yang ditambahkan sehingga panas yang diterima panci semakin stabil.

\section{Kesimpulan}

Kesimpulan dari penelitian ini dan pengujian dilakukan pada ruang terbuka dengan intensitas radiasi matahari berkisar antara $169,6 \mathrm{~W} / \mathrm{m}^{2}$ sampai dengan $974,4 \mathrm{~W} / \mathrm{m}^{2}$ adalah perpindahan kalor konduksi pada panci kompor tenaga surya tanpa tambahan cermin datar 105,15 Watt, tambahan satu cermin datar 174,82 Watt, tambahan dua cermin datar 259,24 Watt, tambahan tiga cermin datar 342,79 Watt dan tambahan empat cermin datar 412,26 Watt. Perpindahan kalor konduksi tergantung dari intensitas matahari yang tertangkap oleh reflector. Jika tiba-tiba intensitas matahari menurun maka temperatur permukaan dinding panci bagian luar (T1) akan menurun ini akan mengakibatkan perbedaan temperatur T1 dan temperatur dinding bagian dalam (T2) akan menjadi sedikit sehingga aliran kalor konduksi pada kompor juga akan menurun. 


\section{Daftar Pustaka}

[1] Giancoli, D.C., 2014, Fisika: Prinsip \& Aplikasi, jilid.1, edisi 7, PT. Penerbit Erlangga, Jakarta.

[2] Bergler, H., Biermann, E., Grupp, M., Owen-Jones, M., and Palmer, R. (1999). Moving Ahead with Solar Cookers, Deutsche Gesellschaft for Tecnische Zusammnenarbeit (GTZ) GmbH, Eschborn, Germany.

[3] Holman, J.P., Alih Bahasa Jasjfi, E., 1997. Perpindahan Kalor, Edisi Keenam. PenerbitErlangga. Jakarta.

[4] Arika Primayosa., Ahmad Qurthobi, S.T., M.T.., 2015, Rancang Bangun Kolektor Panas Matahari Jenis Palung Parabola Dengan Sistem Pelacakan Matahari Menggunakan Sensor Ldr, E-Proceeding Of Engineering.

[5] Azmain Noor Hatuwe, Abdul Hadi Wusurwut, Kelian M.A.S., 2017, Studi Eksperimen Kinerja Oven Surya Berpermukaan Bentuk Oval, Jurnal Simetrik, Jurusan Teknik Mesin, Politeknik Negeri Ambon.

[6] Dwicaksono, M.B., Rangkuti, C., 2017, Perancangan, Pembuatan Dan Pengujian Kompor Energi Matahari Portable Tipe Parabola Kipas, Seminar Nasional Cendekiawan 3 Buku 3 P.41,44.

[7] Marwani., 2011, Potensi Penggunaan Kompor Energi Surya Untuk Kebutuhan Rumah Tangga, Prosiding Seminar Nasional AVoER ke-3 Palembang, 26-27 Oktober 2011.

[8] Muhammad Nomana, Ahmad Wasima, Muzaffar Alib, Mirza Jahanzaiba, Salman Hussaina, Hafiz Muhammad Khurram Alia, Hafiz Muhammad Alib., 2019, An investigation of a solar cooker with parabolic trough concentrator, Mechanical Engineering Department, University of Engineering and Technology, Taxila, Pakistan. 
